\title{
A new species and depth record of bopyrid (Crustacea, Isopoda) from a squat lobster in the Kuril-Kamchatka Trench
}

\author{
Jason D. WILLIAMS ${ }^{1, *}$, Christopher B. BOYKO ${ }^{2}$ \& Ivan N. MARIN ${ }^{3}$ \\ ${ }^{1,2}$ Department of Biology, Hofstra University, Hempstead, New York 11549, USA. \\ ${ }^{2}$ Division of Invertebrate Zoology, American Museum of Natural History, \\ Central Park West at $79^{\text {th }}$ St., New York, New York 10024, USA. \\ ${ }^{3}$ A.N. Severtsov Institute of Ecology and Evolution, Russian Academy of Sciences, Moscow, Russia. \\ *Corresponding author: biojdw@hofstra.edu \\ 2Email: cboyko@amnh.org \\ 33Emails: coralliodecapoda@mail.ru, vanomarin@yahoo.com \\ ${ }^{1}$ urn:1sid:zoobank.org:author:88CDDC0F-C48D-45DF-9F8B-34020FEC39D1 \\ ${ }^{2}$ urn:lsid:zoobank.org:author:2932972A-E5DF-4C4D-A834-8D8A6835357E \\ ${ }^{3}$ urn:1sid:zoobank.org:author:B26ADAA5-5DBE-42B3-9784-3BC362540034
}

\begin{abstract}
The branchial parasitic isopod Pleurocryptella altalis sp. nov. (Bopyridae: Pseudioninae) is described from the squat lobster host Munidopsis petalorhyncha Baba, 2005. The new species is morphologically similar to Pleurocryptella formosa Bonnier, 1900 and P. wolff Bourdon, 1972b but can be distinguished based on male characters (differences in head, pleon and uropods) and female characters (differences in barbula, pleopods and pleotelson). The parasite specimens (a female and male pair) were collected with the squat lobster host at a depth of 5060-5130 m from the Kuril-Kamchatka Trench, representing the deepest record for any of the $850+$ described bopyrid isopod species and for any record of an infested host. Dichotomous identification keys to females and males of Pleurocryptella species and subspecies are provided.
\end{abstract}

Keywords. Ectoparasite, Epicaridea, Pleurocryptella, NW Pacific, Munidopsis.

Williams J.D., Boyko C.B. \& Marin I.N. 2020. A new species and depth record of bopyrid (Crustacea, Isopoda) from a squat lobster in the Kuril-Kamchatka Trench. European Journal of Taxonomy 724: 122-133. https://doi.org/10.5852/ejt.2020.724.1165

\section{Introduction}

The genus Pleurocryptella Bonnier, 1900 is generally considered to be the most primitive genus in Bopyridae Rafinesque, 1815 (Shiino 1965; Bourdon 1979; Markham 1986; Boyko \& Williams 2009, 2010). Females of species in this genus all possess fully developed oostegites on pereomeres $1-5$ and a rudimentary oostegite on each of pereomeres 6 and 7, whereas all other bopyrids lack oostegites on the posterior two pereomeres. Some families of isopods (e.g., Aegidae White, 1850 and Cymothoidae Leach, 1818) that may be basal to bopyrids (Boyko et al. 2013) contain species that possess seven oostegites. 
WILLIAMS J.D. et al., New depth record and species of bopyrid parasite

However, the oostegite number and morphology is not thought to be useful in systematic analyses at higher phylogenetic levels (Brusca \& Wilson 1991) and the presence of oostegites on pereomeres 6 and 7 could actually be a derived feature in Pleurocryptella, but further analysis, ideally using molecular data, is needed.

Although in many genera of bopyrids female characters are of primary taxonomic importance, males of Pleurocryptella provide taxonomically important characters at the genus and species levels. Males of all species of Pleurocryptella have well-developed pleopods, either small and rounded or broad and subquadrate or conical, and articulated uropods; uropods occur on males in only a few other bopyrid genera (e.g., Gigantione Kossmann, 1881; Parapleurocryptella Bourdon, 1972a). Both males and females of species in Pleurocryptella have biarticulated maxilliped palps. While unusual, this condition also occurs in a few other genera (e.g., males and females in species of Parapleurocryptella; males in the species of Goleathopseudione Román-Contreras, 2008 and Pagurocryptella Boyko \& Williams, 2010). To date, ten species and subspecies have been described in Pleurocryptella from galatheid and paguroid hosts (Boyko et al. 2008 onwards), but P. paguri Bourdon, 1979 was transferred to the genus Pagurocryptella (see Boyko \& Williams 2010: table 1 for distribution, depth and host records). Most species of Pagurocryptella and Pleurocryptella are known from deep waters (ca 200-4500 m; Boyko et al. 2012), with only Pleurocryptella infecta infecta Nierstrasz \& Brender à Brandis, 1923 being known from shallower depths (55-183 m; Shiino 1937). Examination of the morphology of all nine described species and subspecies of Pleurocryptella, based on published and unpublished descriptions and illustrations, particularly of males, suggests that more than one phylogenetic lineage is present in the genus. The type species, P. formosa Bonnier, 1900, and P. wolffi Bourdon, 1972b appear to be more closely related to species of Paragigantione Barnard, 1920 than to the other taxa currently placed in Pleurocryptella. In the present paper, we describe a new species of Pleurocryptella that is closely related to $P$. formosa and $P$. wolffi. It is not only the deepest identified bopyrid ever reported, but it is from deeper water than all reported bopyridiform swellings on any decapod hosts.

\section{Material and methods}

The host specimen of Munidopsis petalorhyncha Baba, 2005 and the parasitic isopods were collected in the Kuril-Kamchatka Trench $\left(45^{\circ} 18^{\prime}\right.$ N, $156^{\circ} 00^{\prime}$ E) during the $39^{\text {th }}$ cruise of the R/V 'Vityaz' by Sigsbee trawl at abyssal depths of 5060-5130 m in August 1966 (Birstein \& Zarenkov 1970) and deposited in the collection of the Zoological Museum of Moscow State University (ZMMU), Moscow, Russia. The original fixative used was not recorded; however, according to the museum staff, primary fixation was made with formalin followed by storage in $70 \%$ ethanol that allowed for preservation of the samples in very good condition for a long period of time. For the present study, the parasitic isopods (female and attached male) were carefully extracted from the host's branchial cavity and their morphology was drawn using a camera lucida attached to an Olympus SZX10 light microscope. Measurements were taken to $0.1 \mathrm{~mm}$ with a caliper: the size of the isopods is given as total length (TL) from the front edge of the head to the posterior edge of the pleotelson (exclusive of uropods); carapace length (CL) (with rostrum) and carapace width (CW) are provided for the host specimen (see Komai et al. 2017). The isopod type material and their host are deposited in ZMMU. For those taxonomic authorities not specifically cited in the text, we herein refer the reader to them for ease in locating original descriptions of the taxa (Rafinesque 1815; Latreille 1817; Kossmann 1881; Bonnier 1900; Barnard 1920; Nierstrasz \& Brender à Brandis 1923; Codreanu 1967; Bourdon 1972a, 1972b, 1976, 1981; Markham 1974; Román-Contreras 2008). 


\title{
Results
}

\author{
Order Isopoda Latreille, 1817 \\ Family Bopyridae Rafinesque, 1815 \\ Subfamily Pseudioninae Codreanu, 1967 \\ Genus Pleurocryptella Bonnier, 1900 \\ Pleurocryptella altalis sp. nov. \\ urn:1sid:zoobank.org:act:65006984-C3F1-4C31-ABEF-8225A15F921E
}

Figs $1-3$

“С паразитической изоподой под карапаксом" - Birstein \& Zarenkov 1970: 423, fig. 1.

"parasitic isopod" - Birstein \& Zarenkov 1972: 442, fig. 1.

"bopyrid parasite" - Boyko et al. 2012: 25, table 1. — Marin 2020: 2, figs 1a, $17 \mathrm{f}$.

\section{Etymology}

Combination of Latin words 'altum' ('deep') and 'alis' ('pertaining to') in reference to its occurrence at the greatest depth known for any bopyrid species.

\section{Type material}

\section{Holotype}

KURIL-KAMCHATKA TRENCH • $q(10.4 \mathrm{~mm}$ TL) from right branchial chamber of $₫$ Munidopsis petalorhyncha Baba, 2005 (21.0 mm CL, $15 \mathrm{~mm} \mathrm{CW}$, ZMMU Ma 3504); 39 $9^{\text {th }}$ cruise of R/V 'Vityaz',

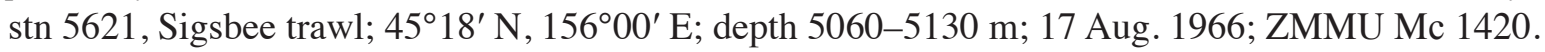

\section{Allotype}

KURIL-KAMCHATKA TRENCH • $1 \hat{\jmath}(4.3 \mathrm{~mm}$ TL); same collection data as for holotype; ZMMU Mc 1421.

\section{Description}

Female (Figs 1B, 2)

Body length $10.4 \mathrm{~mm}$, maximum width $6.8 \mathrm{~mm}$ across pereomere 3, head length $1.9 \mathrm{~mm}$, head width $3.0 \mathrm{~mm}$. Body ovoid, pereon very slightly deflexed dextrally (Figs 1B, 2A), all body regions and pereomeres distinctly segmented. Head subrectangular, broader than long, with frontal lamina extending beyond pereomere 1 and rounded extensions laterally (Fig. 2A), eyes lacking. Barbula with two long, thin, tapering lateral lobes, subequal in length (Fig. 2C). Antennules of three articles each, terminal article minute, setose; antennae of five articles each, terminal article setose (Fig. 2D). Maxilliped (Fig. 2E) with minute setae, most prominent on distal margin, short subacute spur; segmented subcylindrical palp present, with stout setae. Oostegite 1 (Fig. $2 \mathrm{~F}-\mathrm{G}$ ) proximal lobe ovate, distal lobe approximately 50\% narrower than proximal lobe, internal ridge smooth (Fig. 2G).

Pereon of seven pereomeres (Fig. 2A), broadest across pereomere 3, gradually tapering anteriorly and posteriorly; pereomere 1 with convex posterior margin corresponding with posterior margin of head; pereomeres 2-4 straight, pereomeres 5-7 wavy, with progressively greater median concavity and crenulate margins (Fig. 2A). Coxal plates and dorsolateral bosses on pereomeres 1-5 (Fig. 2A), pereomeres $2-3$ with weakly produced tergal projections on right side (Fig. 2A). Oostegites incompletely enclosing marsupium (Fig. 2B), last two pairs of oostegites reduced, plate-like, with setae on margins (Fig. 2L). Pereopods subequal (Fig. 2F-K), with small dactyli and broad bases, setae on all articles except bases; first pair at sides of head, others evenly spaced. 


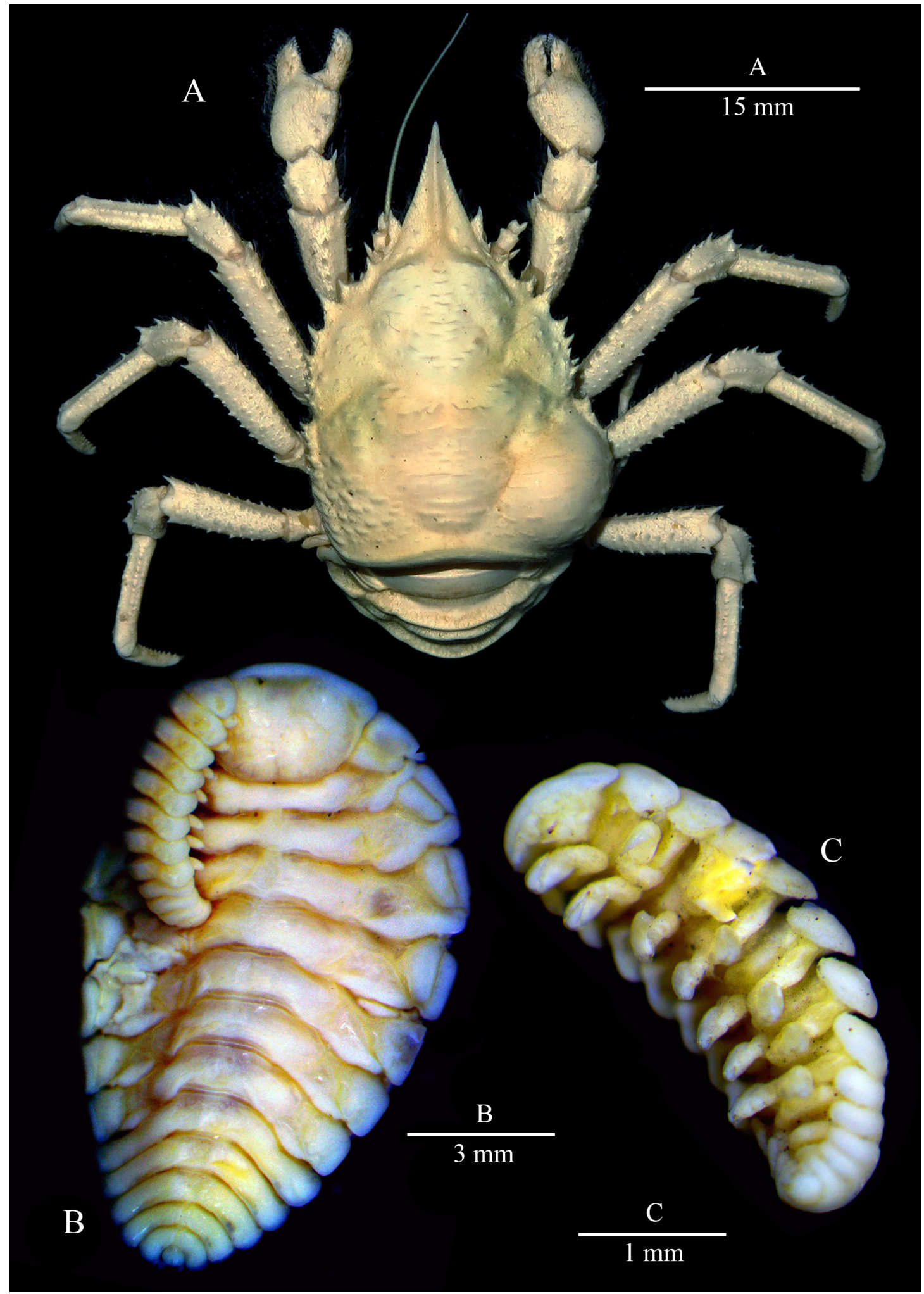

Fig. 1. Micrographs of Pleurocryptella altalis sp. nov. and host Munidopsis petalorhyncha Baba, 2005 (ZMMU Ma 3504). A. Munidopsis petalorhyncha, ô, with swelled right branchial chamber from Pleurocryptella altalis sp. nov. B. Pleurocryptella altalis sp. nov., holotype, ${ }^{+}$, dorsal view (ZMMU Mc 1420) with attached allotype, $\widehat{\partial}$ (ZMMU Mc 1421). C. Pleurocryptella altalis sp. nov., allotype, $\hat{\jmath}$, oblique ventral view (ZMMU Mc 1421). 

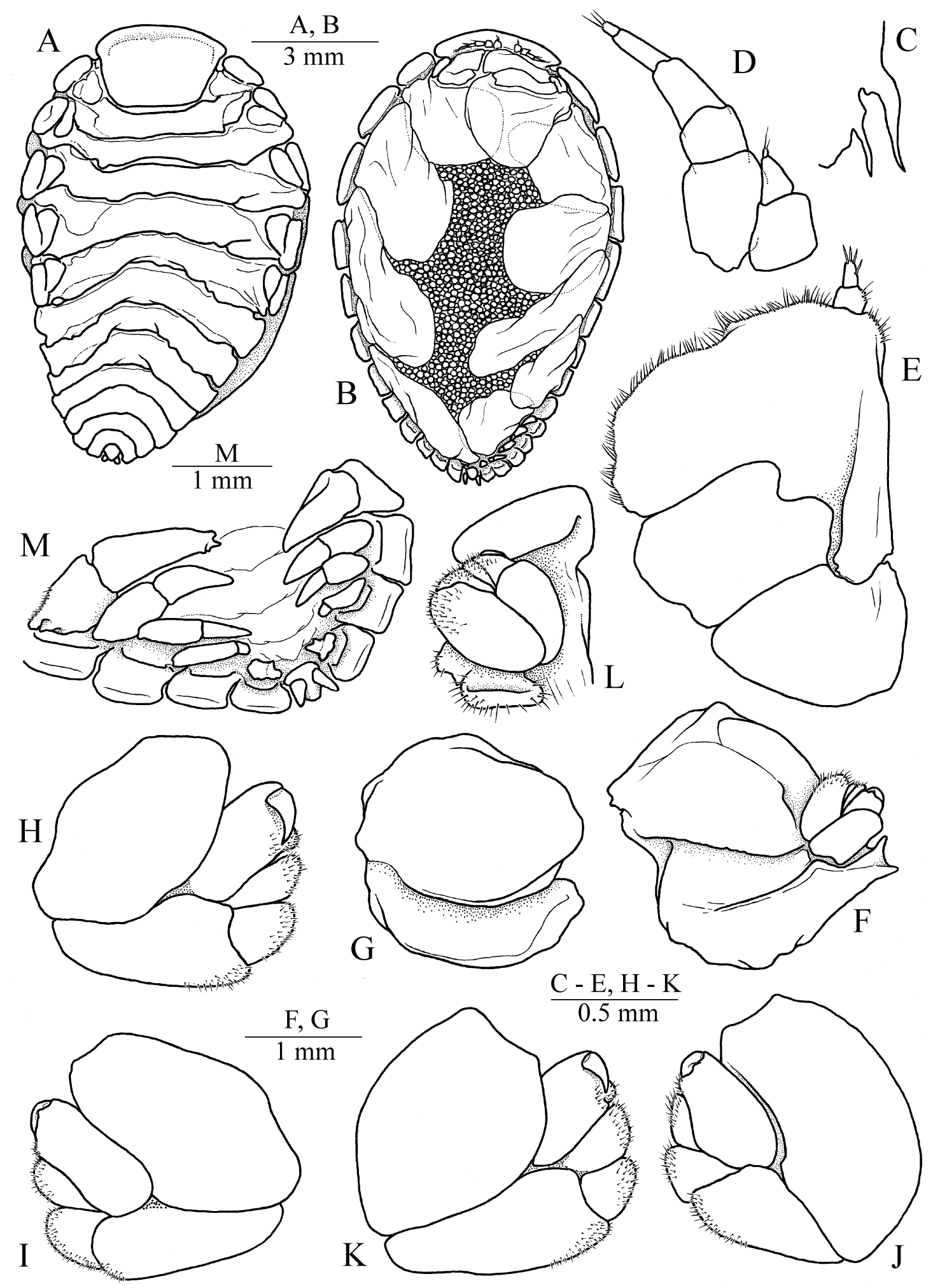

Fig. 2. Pleurocryptella altalis sp. nov., holotype, $\circ$ (ZMMU Mc 1420). A. Dorsal view. B. Ventral view. C. Left barbula. D. Right antennule and antenna. E. Left maxilliped, external view. F. Left oostegite 1, external view with pereopod 1 attached. G. Left oostegite 1, internal view. H-I. Left pereopod 1, lateral view. J-K. Left pereopod 7, lateral view. L. Left pereopod 7 and oostegite, lateral view. M. Pleon, ventral view. 
WILLIAMS J.D. et al., New depth record and species of bopyrid parasite

Pleon with six pleomeres including pleotelson (Fig. 2B, M). Pleomeres 1-4 with biramous, digitiform pleopods, appearing as two stacked articles; pleomere 5 with uniramous, irregularly shaped pleopods; uropods (Fig. 2M) uniramous, tapering distally, directed distolaterally, extending just beyond anal cone.

Male (Figs 1B-C, 3)

Length $4.3 \mathrm{~mm}$, maximum width $1.7 \mathrm{~mm}$, head length $0.5 \mathrm{~mm}$, head width $1.3 \mathrm{~mm}$, pleon length 1.2 $\mathrm{mm}$. Head hemispherical, widest at posterior margin, distinct from pereomere 1 (Figs 1B-C, 3A-B), eyes lacking. Antennules of three articles each, terminal article setose (Fig. 3C); antennae of five articles each, basal three articles with rounded extensions, distal three articles setose (Fig. 3D). Maxilliped bisegmented (Fig. 3E), basal segments small, subrectangular, distal segment elongate with two short, stout setae and four longer, thinner setae on distal end.

Pereomere 4 broadest, others tapering slightly anteriorly and posteriorly (Figs 1B-C, 3A-B). Pereomeres 1-4 approximately straight, pereomeres 5-7 directed posterolaterally, distolateral margins of all pereomeres rounded. Pereopods 1 and 2 (Fig. 3A, F) each with long, curved dactylus extending to carpus; propodus large, broad; carpus and merus small, rounded; ischium and basis elongate; all articles, except dactylus and basis, with small setae. Pereopods 3-7 (Fig. 3A, G-H) subequal, all with shorter dactyli than pereopods 1 and 2, other articles similar to pereopods 1 and 2, bases with slight distal bulge.

Pleon (Figs 1C, 3A, I) of six pleomeres, pleomeres 5-6 curved anteriorly, sides of all pereomeres curled ventrally and overlapping. Broad midventral tubercles on pleomeres $1-4$, reduced one on pleomere 5 (Fig. 3A, I), small, low, rounded pleopods on pleomeres 1-5, mostly obscured by curled lateral margins of pleomeres (Fig. 3I). Pleotelson bearing articulated, triangular-shaped uropods (Fig. 3A, I) extending beyond anal cone.

\section{Note on host identification}

The host was originally identified as the holotype of Munidopsis subsquamosa latimana Birstein \& Zarenkov, 1970, but, because that name is a junior homonym of M. latimana Miyake \& Baba, 1966, Baba (2005) proposed the replacement name M. petalorhyncha Baba, 2005.

\section{Remarks}

The new species appears most closely related to Pleurocryptella formosa and P. wolffi. Males of these three species all have low, broad midventral tubercles on pleomeres 1-4 that cover nearly all of the space between the pleopods, whereas males of all other species in the genus have small, semispherical tubercles on the pleomeres that do not cover the space between the pleopods. Both sexes of Pleurocryptella altalis sp. nov. are distinguishable from those of $P$. formosa and $P$. wolffi. Males of $P$. altalis sp. nov. have the lateral margins of the pleomeres curled laterally and covering the pleopods in ventral view (also curled in $P$. wolffi, but splayed laterally and pleopods visible in ventral view in $P$. formosa), the head nearly as broad as pleomere 1 (also as broad in $P$. wolffi but much narrower than pleomere 1 in $P$. formosa), and the uropods larger than pleopod 5 (uropods smaller than pleopod 5 in $P$. wolffi and the same size as pleopod 5 in $P$. formosa). Females of $P$. altalis sp. nov. have the barbula with two acute, slender lobes of approximately the same length (barbula with outer lobe tapered but much broader, inner lobe much shorter than outer and rounded in $P$. wolffi and $P$. formosa), pleopod 5 less than half as large as pleopod 4 and uniramous (pleopod 5 more than half as large as pleopod 4 and biramous in $P$. wolffi and $P$. formosa), and pleomeres smoothly curved with pleomere 5 not surrounding pleotelson (pleomeres smoothly curved, but surrounding pleotelson in $P$. wolffi and not smoothly curved (angular middle portion) and not surrounding pleotelson in $P$. formosa).

\section{Key to females of species of Pleurocryptella Bonnier, 1900}

1. Uropods surrounded by distolateral margins of pleomere 5 ....................... P. wolffi Bourdon, 1972b

- Uropods not surrounded by distolateral margins of pleomere 5 


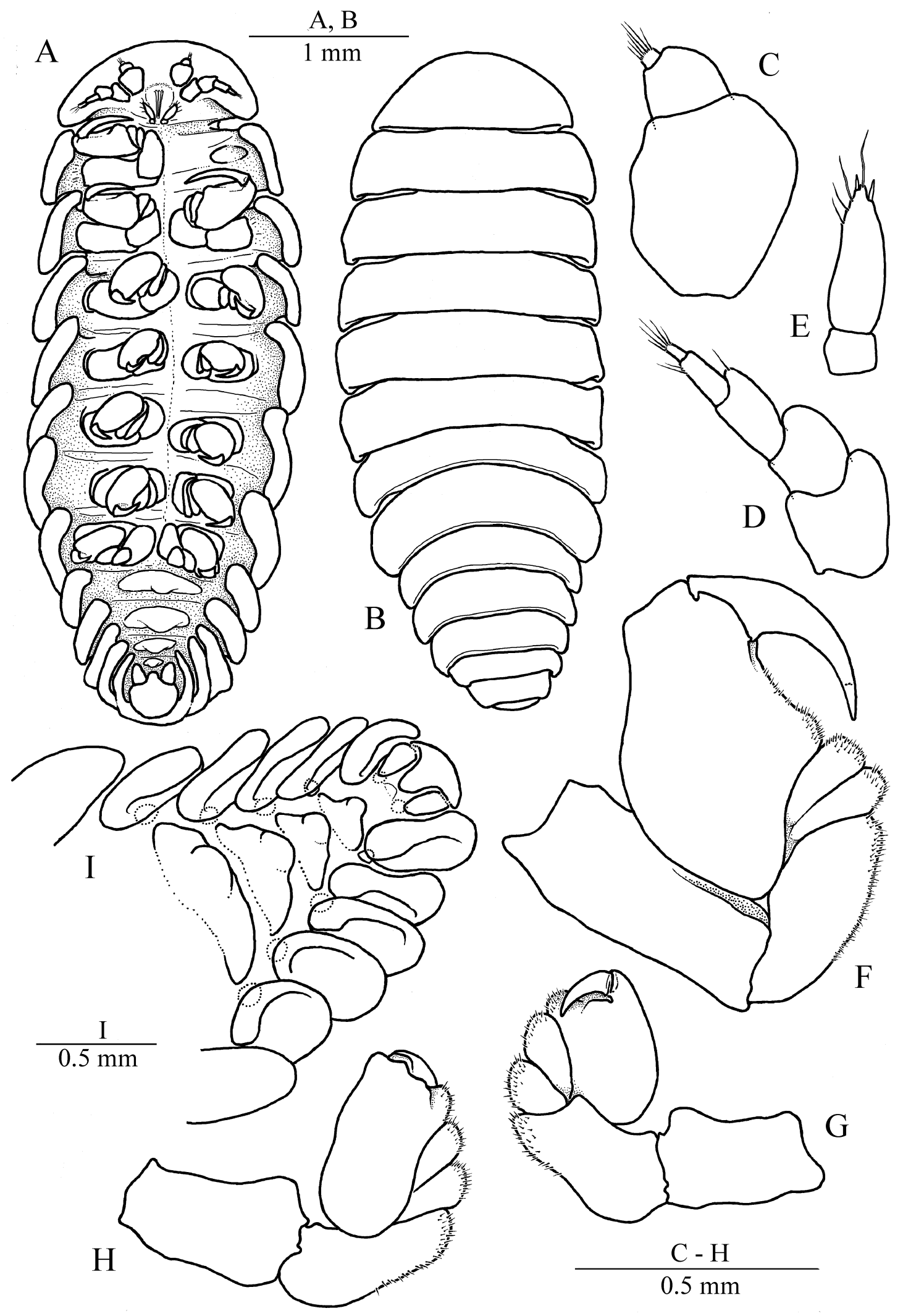

Fig. 3. Pleurocryptella altalis sp. nov., allotype, $\widehat{\partial}$ (ZMMU Mc 1421). A. Ventral view. B. Dorsal view. C. Right antennule. D. Right antenna. E. Right maxilliped. F. Right pereopod 1, lateral view. G-H. Left pereopod 7, lateral view. I. Pleon, ventral view (pleopods shown in dashed lines). 
WILLIAMS J.D. et al., New depth record and species of bopyrid parasite

2. Uropods shorter than pleotelson, scarcely projecting beyond distolateral margins of pleomere $5 \ldots 3$

- Uropods longer than pleotelson, projecting well beyond distolateral margins of pleomere 5 .......... 5

3. Total body length and width subequal; pronounced digitations on pereomeres of long side.

P. formosa Bonnier, 1900

- Body much longer than wide

4. Posterior margins of all pereomeres smooth.

P. fimbriata Markham, 1974

- Posterior margins of pereomeres 5-7 wavy P. altalis sp. nov.

5. Antenna with 6 segments.

P. crassandra Bourdon, 1976

- Antenna with 5 segments.

6. Body strongly tapering from anterior to posterior, head not extending beyond anterolateral margins of pleomere 1

- Body gradually tapering from anterior to posterior, head extending beyond anterolateral margins of pleomere 1

7. Lobes of barbula distally acute, outer lobe approximately three times as long as inner lobe

P. laevis (Richardson, 1910) ${ }^{* *}$

- Lobes of barbula distally rounded, outer lobe approximately twice as long as inner lobe.

P. superba Bourdon, 1981

8. Pleotelson and uropods ventral to pleomere 5; pronounced digitations (tubercles) on pereomeres of short side

P. infecta tuberculata Bourdon, 1976

- Pleotelson and uropods between pleomere 5 in ventral view; lacking pronounced digitations (tubercles) on pereomeres. P. infecta infecta Nierstrasz \& Brender à Brandis, 1923

* Pleurocryptella latimellaris (Nierstrasz \& Brender à Brandis, 1931) not included in the key.

${ }^{* *}$ Data for P. laevis based on Bourdon (unpublished MS).

\section{Key to males of species of Pleurocryptella Bonnier, 1900*}

1. Midventral tubercle on pleomere 7

P. wolffi Bourdon, 1972b

- No midventral tubercle on pleomere 7

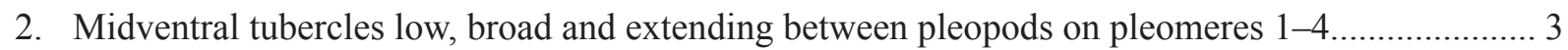

- Midventral tubercles small, semispherical and medially situated .................................................... 4

3. Lateral margins of pleomeres strongly curled ventrally, covering pleopods P. altalis sp. nov.

- Lateral margins of pleomeres slightly curled ventrally, not covering pleopods

P. formosa Bonnier, 1900

4. Midventral tubercles only on pleomeres 1-3

P. laevis (Richardson, 1910) ${ }^{* *} \&$ P. infecta tuberculata Bourdon, $1976^{* * *}$

- Midventral tubercles on more than pleomeres 1-3.

5. Midventral tubercles on pleomeres 1-4

P. fimbriata Markham, 1974

- Midventral tubercles on pleomeres 1-5.

6. Pleon markedly narrower than pereon........ P. infecta infecta Nierstrasz \& Brender à Brandis, 1923

- Pleon not markedly narrower than pereon. 
7. Antenna with 7 segments.....

P. crassandra Bourdon, 1976

- Antenna with 5 segments. P. superba Bourdon, 1981

* Pleurocryptella latimellaris (Nierstrasz \& Brender à Brandis, 1931) not included in the key.

** Data for P. laevis based on Bourdon (unpublished MS).

${ }^{* * *}$ Based on published and unpublished data, the males of $P$. laevis and P. infecta tuberculata are indistinguishable.

\section{Discussion}

In light of the marked differences between the males of the various species of Pleurocryptella, a thorough revision of the genus is warranted. Richardson (1910) incompletely described and figured P. laevis, but Bourdon (unpublished) later redescribed it on the basis of the types and other material. Fortunately, one of us (CBB) was given a copy of Bourdon's MS during a visit to the Muséum national d'histoire naturelle (MNHN) in 2002, which has aided in the production of our key to species (see above). Likewise, Pseudione latilamellaris was incompletely described and illustrated by Nierstrasz \& Brender à Brandis (1931) and was placed in Pleurocryptella by Bourdon (1979) without comment as to the reason for this placement. Several characters of the male and female of $P$. latilamellaris suggest that this species is not congeneric with the other species of Pleurocryptella, even if the females possess the rudimentary oostegites on pleomeres 6 and 7 .

Pleurocryptella altalis sp. nov. represents the deepest record for any bopyrid parasite, including all described species and unidentified bopyridiform swellings on hosts. Although the depth of the host's collection has previously been given as 5035-5210 m (Birstein \& Zarenkov 1970, 1972; Baba 2005) or 5025-5210 m (Boyko et al. 2012), the actual depth is 5060-5130 m (Komai et al. 2017; Marin 2020). The host species, Munidopsis petalorhyncha, is also recorded from the east slope of the Iwaki Seamount off the coast of Japan at greater depths (5353-5380 m; see Komai et al. 2017), and it is possible that the bathymetric and geographic ranges of the parasite are similar to those of its host, although parasites often occur only in a portion of the range of a host species (Pielou 1974). Boyko \& Williams (2010: table 1) provided depth and host records for the described species and subspecies of Pleurocryptella and related genera.

\section{Acknowledgments}

Thanks to Alain Crosnier for sharing a copy of Bourdon's unpublished MS. This study was partly supported by the Russian Foundation of Basic Researches (RFBR) with grant number 18-04-01093_A awarded to IM.

\section{References}

Baba K. 2005. Deep-sea chirostylid and galatheid crustaceans (Decapoda: Anomura) from the IndoPacific, with a list of species. Galathea Report 20: 1-317.

Barnard K.H. 1920. Contributions to the crustacean fauna of South Africa. No. 6. Further additions to the list of marine Isopoda. Annals of the South African Museum 17: 319-348.

https://doi.org/10.5962/bhl.part.22318

Birstein Y.A. \& Zarenkov N.A. 1970. Bottom decapods (Crustacea Decapoda) of the Kurile-Kamchatka Trench area. Akademiya Nauk SSSR. Trudy Instituta Okeanologii im P.P. Shirshova 86: 420-426. [In Russian.]

Birstein Y.A. \& Zarenkov N.A. 1972. Bottom decapods (Crustacea Decapoda) of the Kurile-Kamchatka Trench area. In: Bogorov V.G. (ed.) Fauna of the Kurile-Kamchatka Trench and its Environment based 
WILLIAMS J.D. et al., New depth record and species of bopyrid parasite

on Data of the $39^{\text {th }}$ Cruise of the R/V "Vityaz". Akadamiya Nauk SSSR, Trudy Instituta Okeanologii im P.P. Shirshova 86: 439-447. Israel Program for Scientific Translation, Jerusalem. [Note that "Birshtein" is consistently used in this paper, but is an alternate transliteration from the Russian "Бирштейн"; wе use "Birstein" as found in his other publications, although the name should actually be "Birštein" with the appropriate diacritical mark.]

Bonnier J. 1900. Contribution à l'étude des épicarides. Les Bopyridae. Travaux de la Station zoologique de Wimereux 8: 1-476. https://doi.org/10.5962/bhl.title.10522

Bourdon R. 1972a. Sur quelques Bopyridae (Crustacea, Isopoda) parasites de galathéides. Bulletin du Muséum national d'histoire naturelle, $3^{e}$ Série 66 (Zoologie 52): 817-838.

Available from https://www.biodiversitylibrary.org/part/272602 [accessed 17 Nov. 2020].

Bourdon R. 1972b. Epicarides de la Galathea Expedition. Galathea Report 12: 101-112.

Bourdon R. 1976. Épicarides de Madagascar. I. Bulletin du Muséum national d'histoire naturelle, $3^{e}$ Série 371 (Zoologie 259): 353-392.

Available from https://www.biodiversitylibrary.org/part/280629 [accessed 24 Nov. 2020].

Bourdon R. 1979. Bopyridae de la campagne Biaçores (Isopoda Epicaridea). Bulletin du Muséum national d'histoire naturelle, 4 e Série 1 (A(2)): 507-512.

Available from https://www.biodiversitylibrary.org/part/283205 [accessed 17 Nov. 2020].

Bourdon R. 1981. Bopyriens nouveaux pour la faune Européenne de l'Atlantique (Isopoda Epicaridea). Bulletin du Muséum national d'histoire naturelle, 4e Série, 3 (A(2)): 615-634.

Available from https://www.biodiversitylibrary.org/part/285839 [accessed 24 Nov. 2020].

Boyko C.B. \& Williams J.D. 2009. Crustacean parasites as phylogenetic indicators in decapod evolution. In: Martin J.W., Crandall K.A. \& Felder D.L. (eds) Crustacean Issues 18. Decapod Crustacean Phylogenetics: 197-220. CRC Press, Boca Raton. https://doi.org/10.1201/9781420092592

Boyko C.B. \& Williams J.D. 2010. A new genus and species of primitive bopyrid (Isopoda, Bopyridae) parasitizing hermit crabs (Anomura) from deep waters in the eastern Atlantic and Japan. In: Fransen C.H.J.M., de Grave S. \& Ng P.K.L. (eds) Crustacean Monographs 14. Studies on Malocostraca: Lipke Bijdeley Holthuis Memorial Volume: 145-157. Brill, Leiden.

https://doi.org/10.1163/9789047427759_007

Boyko C.B., Bruce N.L., Hadfield K.A., Merrin K.L., Ota Y., Poore G.C.B., Taiti S., Schotte M. \& Wilson G.D.F. (eds). 2008 onwards. World Marine, Freshwater and Terrestrial Isopod Crustaceans database. Pleurocryptella Bonnier, 1900.

Available from http://www.marinespecies.org/aphia.php?p=taxdetails\&id=118183 [accessed 23 Jun. 2020].

Boyko C.B., Williams J.D. \& Markham J.C. 2012. Recent and fossil Isopoda Bopyridae parasitic on squat lobsters and porcelain crabs (Crustacea: Anomura: Chirostyloidea and Galatheoidea), with notes on nomenclature and biogeography. Zootaxa 3150: 1-35. https://doi.org/10.11646/zootaxa.3150.1.1

Boyko C.B., Moss J., Williams J.D. \& Shields J.D. 2013. A molecular phylogeny of Bopyroidea and Cryptoniscoidea (Crustacea: Isopoda). Systematics and Biodiversity 11: 495-506.

https://doi.org/10.1080/14772000.2013.865679

Brusca R.C. \& Wilson G.D.F. 1991. A phylogenetic analysis of the Isopoda with some classificatory recommendations. Memoirs of the Queensland Museum 31: 143-204.

Available from https://www.biodiversitylibrary.org/part/97765 [accessed 17 Nov. 2020].

Codreanu R. 1967. Clasificarea evolutiva a bopirienilor, isopode parazite ale crustaceelor decapode si importanta lor biologica generala. Studii si Cercetari de Biologie Seria Zoologie 19: 203-211. 
Komai T., Marin I. \& Kakui K. 2017. Rediscovery and redescription of the abyssal squat lobster Munidopsis petalorhyncha Baba, 2005 (Crustacea: Decapoda: Munidopsidae) from the Northwest Pacific. Zootaxa 4226: 93-102. https://doi.org/10.11646/zootaxa.4226.1.4

Kossmann R. 1881. Studien über Bopyriden. Zeitschrift für Wissenschaftliche Zoologie 35: 652-680.

Latreille [P.A.] 1817. Les Crustacés, les Arachnides et les Insectes. In: Cuvier G. (ed.) Le Règne Animal distribué d'après son Organisation, pour servir de Base à l'Histoire naturelle des Animaux et d'Introduction à l'Anatomie comparée. Vol. 3: 1-653. Deterville, Paris.

Available from https://www.biodiversitylibrary.org/page/28833400 [accessed 18 Nov. 2020].

Marin I. 2020. Northern unicorns of the depths: diversity of the genus Munidopsis Whiteaves, 1874 (Decapoda: Anomura: Munidopsidae) in the northwestern Pacific Ocean, with descriptions of three new species along the Russian coast. Progress in Oceanography 183: 102263.

https://doi.org/10.1016/j.pocean.2020.102263

Markham J.C. 1974. Six new species of bopyrid isopods parasitic on galatheid crabs of the genus Munida in the western Atlantic. Bulletin of Marine Science 23: 613-648.

Markham J.C. 1986. Evolution and zoogeography of the Isopoda Bopyridae, parasites of Crustacea Decapoda. In: Gore R.H. \& Heck K.L. (eds) Crustacean Issues 4. Crustacean Biogeography: 143-164. A.A. Balkema, Rotterdam. https://doi.org/10.1201/9781315140674-7

Nierstrasz H.F. \& Brender à Brandis G.A. 1923. Die Isopoden der Siboga-Expedition. II. Isopoda genuina. I. Epicaridea. Siboga-Expeditie 32b: 57-121.

Nierstrasz H.F. \& Brender à Brandis G.A. 1931. Papers from Dr. Th. Mortensen's Pacific Expedition 1914-16. LVII. Epicaridea II. Videnskabelige Meddedelser fra den Dansk Naturhistoriske Forening $i$ København 91: 147-226.

Pielou E.C. 1974. Biogeographic range comparisons and evidence of geographic variation in hostparasite relations. Ecology 55: 1359-1367. https://doi.org/10.2307/1935463

Rafinesque C.S. 1815. Analyse de la Nature ou Tableau de l'Univers et des Corps organisés. Self published, Palermo. https://doi.org/10.5962/bhl.title.106607

Richardson H. 1910. Marine isopods collected in the Philippines by the U.S. Fisheries steamer Albatross in 1907-8. Bureau of Fisheries Document 736: 1-44. https://doi.org/10.5962/bhl.title.82673

Román-Contreras R. 2008. A new genus of bopyrid isopod infesting Munidopsis beringana (Decapoda: Galatheidae) from deep waters. Journal of Crustacean Biology 28: 378-384.

https://doi.org/10.1163/20021975-99990383

Shiino S.M. 1937. Some additions to the bopyrid fauna of Japan. Annotationes Zoologicae Japonenses 16: 293-300.

Shiino S.M. 1965. Phylogeny of the genera within the family Bopyridae. Bulletin du Muséum national d'histoire naturelle, Série 2 37: 462-465.

Manuscript received: 30 June 2020

Manuscript accepted: 16 September 2020

Published on: 26 November 2020

Topic editor: Rudy Jocqué

Desk editors: Connie Baak and Kristiaan Hoedemakers 
WILLIAMS J.D. et al., New depth record and species of bopyrid parasite

Printed versions of all papers are also deposited in the libraries of the institutes that are members of the EJT consortium: Muséum national d'histoire naturelle, Paris, France; Meise Botanic Garden, Belgium; Royal Museum for Central Africa, Tervuren, Belgium; Royal Belgian Institute of Natural Sciences, Brussels, Belgium; Natural History Museum of Denmark, Copenhagen, Denmark; Naturalis Biodiversity Center, Leiden, the Netherlands; Museo Nacional de Ciencias Naturales-CSIC, Madrid, Spain; Real Jardín Botánico de Madrid CSIC, Spain; Zoological Research Museum Alexander Koenig, Bonn, Germany; National Museum, Prague, Czech Republic. 